\title{
EFFECT OF HISTORIC TIMBER ROOF STRUCTURES ON THE STRUCTURAL BEHAVIOUR OF MASONRY BUILDINGS DURING SEISMIC EVENTS
}

\author{
ALEXANDRA I. KELLER ${ }^{1,2^{*}}$, MARIUS MOSOARCA ${ }^{1,2}$ \\ ${ }^{1}$ Politehnica University of Timisoara, Faculty of Architecture and Urban Planning \\ 2/A Traian Lalescu, Zip code 300223, Timișoara, Romania \\ e-mail: alexandra.keller@upt.ro (*corresponding author),marius.mosoarca@upt.ro \\ ${ }^{2}$ Politehnica University of Timisoara, Urban Planning and Architecture research centre \\ 2/A Traian Lalescu, Zip code 300223, Timișoara, Romania
}

Keywords: Historic timber roof structure, Historic masonry structure, seismic events

\begin{abstract}
Roofs are complex elements of heritage structures which are not only meant to protect the building from exterior methodological factors but are also defining the skyline of a city while highlighting the importance and aesthetics of the building they belong to. However, in seismic areas, roof structures prove out to either trigger the out-of-plane behaviour of historic masonry buildings [1] or reduce the horizontal displacement, depending on their type and their connection to the masonry walls [2]. The study is therefore aiming do highlight the effect of common roof structure types from Timisoara, a city placed in the western part of Romania, subjected to shallow earthquakes, on the seismic behaviour of a local type of masonry structure, with a ground-floor and 2 upper floors, from the 18th century.
\end{abstract}

Throughout the study, three different types of roof structures were placed on the same masonry building and the out-of-plane horizontal displacement, inter-story drift, damage level and internal forces were assessed. The main scope of the study is to highlight how the chosen roof structures from the $18^{\text {th }}, 19^{\text {th }}$ and $20^{\text {th }}$ century, would influence the behaviour of a masonry building during seismic events. Detailed numerical simulations using finite element models of the building and the three roof structures were performed in order to obtain the four assessed parameters, which prove that, depending on the connection to the masonry walls and the state of conservation of the timber elements, roof structures would significantly improve the seismic behaviour of historic masonry buildings in this area.

\section{INTRODUCTION}

Heritage buildings were built considering the local environmental factors, by taking all the risks into consideration and adapting the structural features of the building in order to ensure good structural behaviour during extreme events. This can strongly be observed in earthquakeprone areas, where various solutions were found in order to reduce the seismic vulnerability of the heritage structures which are able to preserve the integrity of the building and ultimately save the life of their inhabitants $[3,4]$. More recent studies also confirm that roof structures can 
influence the seismic behaviour of historic masonry buildings. More than that, they also highlight that the connection between the roof structure and the state of conservation of the timber joints is also significantly influencing the behaviour of the roof structure and ultimately that of the masonry building during that seismic event $[5,6]$. It can, therefore, be stated that timber structures can enhance the seismic behaviour of historic masonry building $[7,8]$ but also in a bad state of conservation trigger significant damage $[9,10]$.

Considering this observations, a study has been performed in Timisoara, concerning the effect of three representative roof structure types on the seismic behaviour of a characteristic historic masonry building from the $18^{\text {th }}$ century by evaluating the out of plane displacement of the walls, their damage level and the internal forces by also highlighting the effect of the decay of the timber elements on this behaviour [11].

\section{NUMERICAL MODELING OF THE BUILDING AND ROOF STRUCTURES}

Finite element numerical simulations have been performed using the structural analysis software SCIA engineer [12]. By using the equivalent lateral forces method, the software is performing a static seismic behaviour analysis of the model, based also on dynamic analysis data like the defined seismic response spectrum and the distribution of the masses on each floor of the building. Thus, for the numerical simulation, the local characteristics of the earthquake were taken into consideration. The western part of Romania is the second seismic area of the country regarding the seismic intensity [13] but is mainly influenced by rather shallow earthquakes, which are only producing significant damage starting with 8 kilonetres around
the epicentre [14]. 94 seismic events with a seismic intensity between V and VIII on the
Mercalli scale were rocorded in the region [15,16].
2.1 Characteristics of the building

For the numerical simulations, a characteristic building from the historic part of the city was Register for free at https//WwW.scipedia.com to gownload the version without the watermark

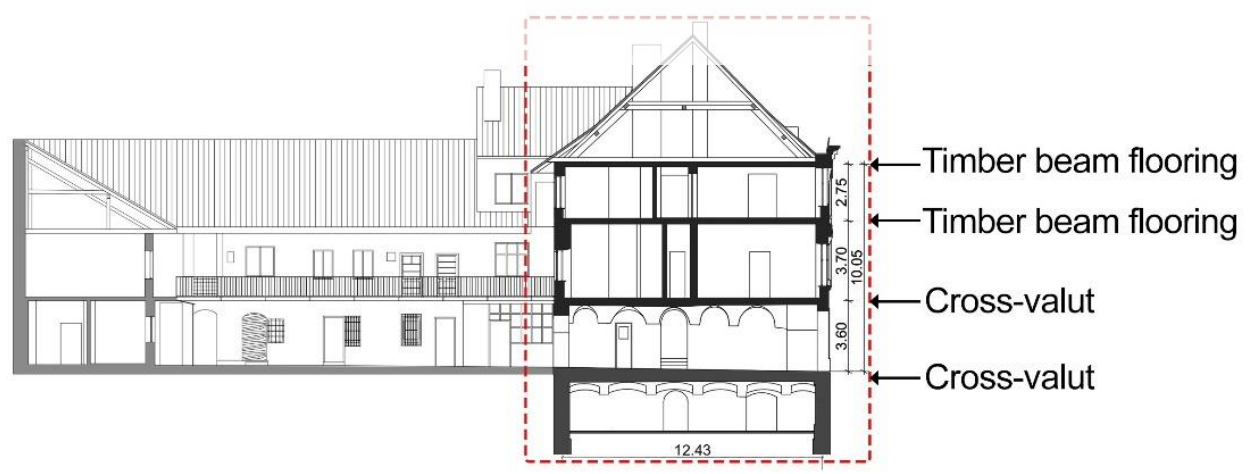

Figure 1: Section of the $18^{\text {th }}$ century building - marked area which was considered for the study

The building has an L shaped plan, with the main building placed parallel to the street and a secondary wing placed towards the courtyard, perpendicular to the street. Therefore, for the study, only the main building was considered. It has one underground floor and three levels above ground each of them presenting a different functional purpose. Therefore, the ground 
floor was used for commercial purposes while the two upper floors where residential. The structure is also changing with the height of the building, the width of the historic masonry walls decreasing from 90 centimetres at the ground floor down to 45 at the top of the building, while the floor structure is changing from cross vaults used for the ground floor to timber beam flooring at the upper floors.

Unfortunately, due to low maintenance the building was partially demolished and an up to date hotel is planned to be built instead.

\subsection{Characteristics of the roof structures}

The three chosen structures are not only the main roof structure types which can be found in the city, until the beginning of the $20^{\text {th }}$ century, they are also specific for the period in which they were built. This is why a characteristic roof structure from the $18^{\text {th }}, 19^{\text {th }}$ and beginning of the $20^{\text {th }}$ century was chosen for the study (Figure 2). The three structures are all purlin roof structures composed of main and secondary trusses, but they present completely different approaches regarding the used structural elements, their cross-section and their position, therefore influencing the seismic behaviour of the building in different ways.
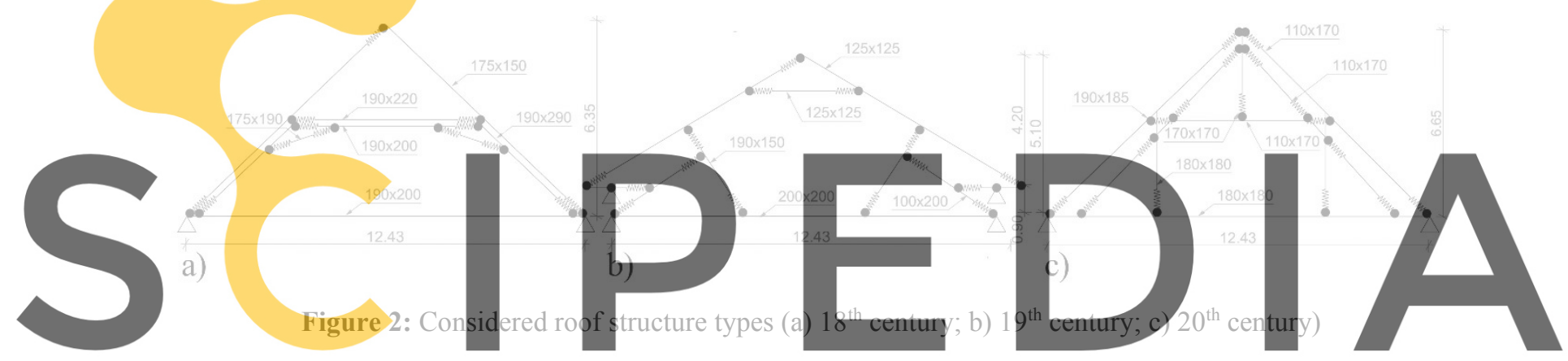

The $18^{\text {th }}$-century roof structure (Figure $2 \mathrm{a}$ ) is presenting a complex strutting device, specific

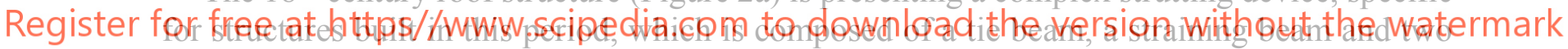
compound rafters. Additionally, a second layer of structural elements was placed on the exterior of the strutting device, composed of a collar beam and the two rafters meant to compose the support of the roof envelope. At the same time, the roof structure is also presenting a complex system of diagonal elements placed between the rafters meant to also increase its rigidity in the longitudinal direction. The connection to the wall is made by a wall plate, partially inserted in the historic masonry wall and connected to the tie beam through a traditional crafted lap joint.

The 19th century roof structure (Figure 2b) is rather peculiar since it is a queen-post structure with inclined post and without a collar beam connecting the top part of the posts. Still, an angle brace was placed in the upper part of the structure, connecting only the rafters. This roof structure is also presenting a different type of longitudinal rigidity enhancing system, which is composed of heathers and trimmers and placed above the masonry wall.

The beginning of the $20^{\text {th }}$ century roof structure type (Figure $2 \mathrm{c}$ ) is a typical queen and king post structure with two queen posts placed in the inferior part of the structure and one king post placed above the collar beam meant to increase the height of the roof. In this case, no additional rigidity enhancing system was observed in the longitudinal direction.

For the $19^{\text {th }}$ and $20^{\text {th }}$ century roof structures passing braces were used to connect the posts to 
the tie-beam. At the same time, it was observed that the used cross-section of the timber elements is lower than in the $18^{\text {th }}$ century roof structure case. Except for the tie beam to wall plate joint which is a lap joint, all the other joints are tenon and mortise joints with or without additional wooden and steels pegs, depending on their position.

\subsection{Characteristics of the models}

Due to the significant height of the roof structures, it was impossible to assess their behaviour in a laboratory and numerical simulations were performed by placing each of the three chosen roof structures on the characteristic $18^{\text {th }}$ century historic masonry building in SCIA Engineer. For both the building and the roof structure, the surveyed geometric characteristics of the structural elements were used in the models. For the models, the timber elements of the roof structures were modelled 1D members and the masonry walls as orthotropic 2D elements. Concerning the material properties, it was decided to use code-based mechanical properties for the timber (D18) and the historic masonry [11], since only few laboratory tests have been performed on historic timber and brick in Timisoara.

Previously performed studies concerning the behaviour of historic timber roof structures and their effect on masonry structures are highlighting the importance of properly considering the connection between the roof and the wall but also the significant effect of the joint axial stiffness on the general behaviour of the roof structure. Therefore, during the study, three different support types were taken into consideration: rigid, sliding and hinged and sliding, while the joins were modelled modelling them as rigid using three different method $[19,20]$ and the roof structure model.
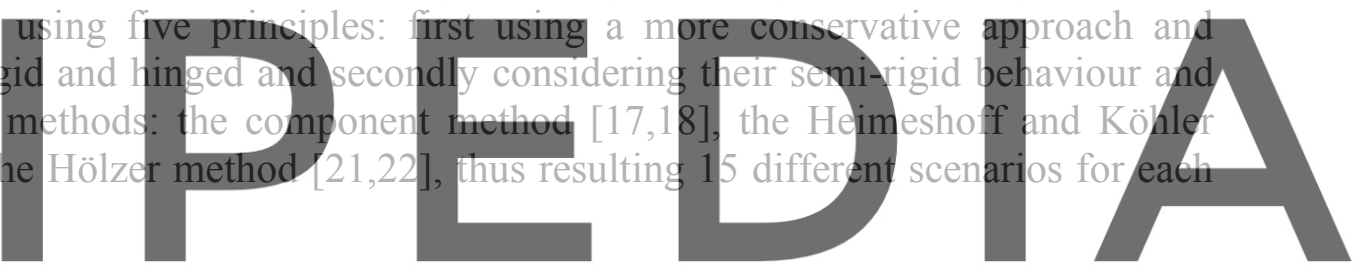

3 RESULTS

Register for free at https//www.scipedia.com to download the version without the watermark masonry building during local seismic events was analysed by comparing five parameters, which could highlight if the roof structures are actually improving the seismic behaviour of the chosen historic masonry building and which one is presenting the best effect (Figure 3).

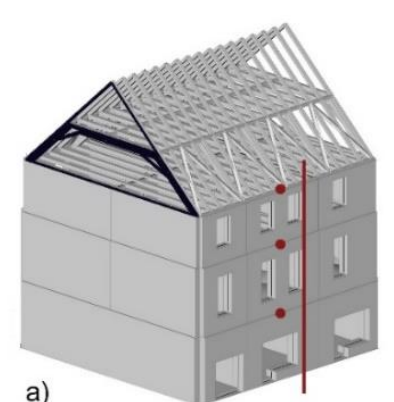

- Points where the out-of-plane horizontal displacement and inter-story drift were measured Section where the internal forces were obtained

Figure 3: The three models with roof structures (a) $18^{\text {th }}$ century; b) $19^{\text {th }}$ century; c) $20^{\text {th }}$ century) (after [11]) 
Therefore the horizontal out-of-plane displacement and inter-story drift of a selection of points, placed on a longitudinal exterior wall in the area of each slab, but also the deformed shape of the building, the damage level of the masonry wall on each floor and the internal forces were considered.

\subsection{Out-of-plane displacement}

First in order to observe the effect of the roof structures on the seismic behaviour of the masonry building the out-of-plane displacement of the building without roof structure was compared with the results obtained for the same building with the three chosen roof structures.

While comparing the results, it was observed that the out-of-plane displacement is approximately similar on the first floor of the building with variations reaching up to $10 \%$ compared to the no roof structure building. The presence of the $20^{\text {th }}$ century roof structure is causing the most peculiar behaviour of the building since it presents the lowest horizontal displacement at the first and second floor but the highest displacement at the top, decreasing it with only $20 \%$ compared to the no roof structure case. Compared to this, the presence of the $18^{\text {th }}$ century roof is presenting the most significant improvement of the top out-of-plane displacement, reducing the displacement with about $50 \%$, while the $19^{\text {th }}$ century roof structure is reducing it with around $40 \%$. Still, in all the three cases, a difference between the obtained displacements was observed influenced by the considered scenarios (Table 1, Figure 4).

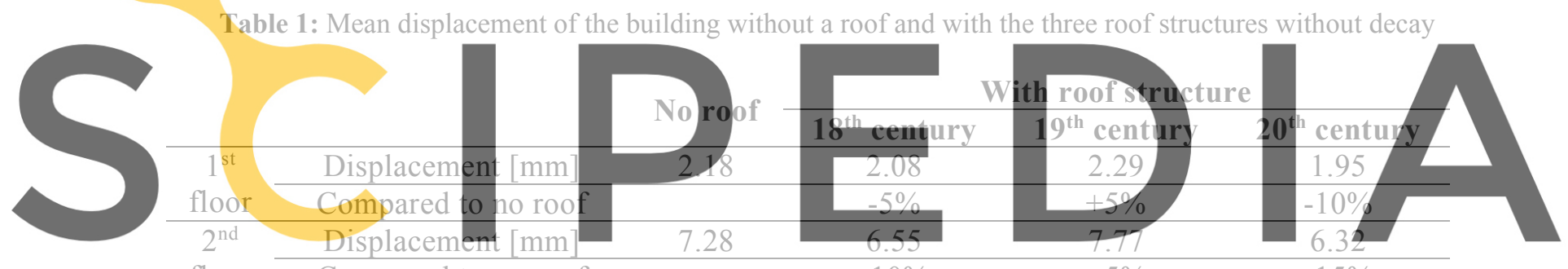

floor Compared to no roof $-10 \%$

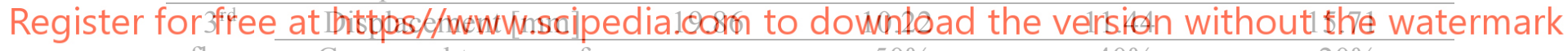

floor Compared to no roof
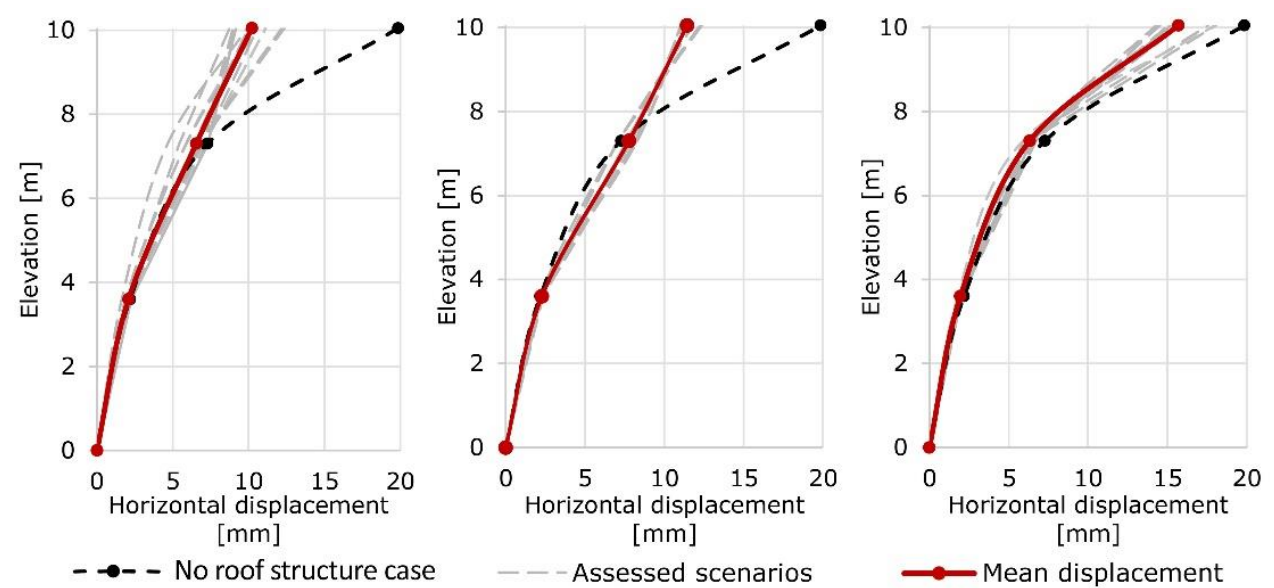

Figure 4: Horizontal out-of-plane displacement of the building without and with roof structures (a) 18th century; b) 19 th century; c) 20th century) without decay 
If, however, the timber elements are decayed, the numerical simulations highlight that the effect of the roof structures is different (Table 2, Figure 5). It can be observed that the presence of the $20^{\text {th }}$ century roof structure is causing a slight increase of the horizontal displacement at the first and second floor but still reducing the top horizontal displacement with about $30 \%$, more than is the case with the same roof structure in a good state of conservation. At the same time, it could be observed that the $19^{\text {th }}$ century structure is also increasing the horizontal displacement on the first floors while significantly reducing the top horizontal displacement with up to $40 \%$. The $18^{\text {th }}$ century rood structure, on the other hand, is still presenting a reduction of the horizontal displacement at the first and second floor, but only a $40 \%$ reduction at the top. Still, compared to the displacement recorded for the $19^{\text {th }}$ and $20^{\text {th }}$ century roof structure, where the differences between the assessed scenarios are rather low, in the case of the $18^{\text {th }}$ century roof, a clear variation depending on the chosen to support and joined axial stiffness was observed reaching up to $25 \%$.

Table 2: Mean displacement of the building without a roof and with the three roof structures with 20\% decayed timber elements

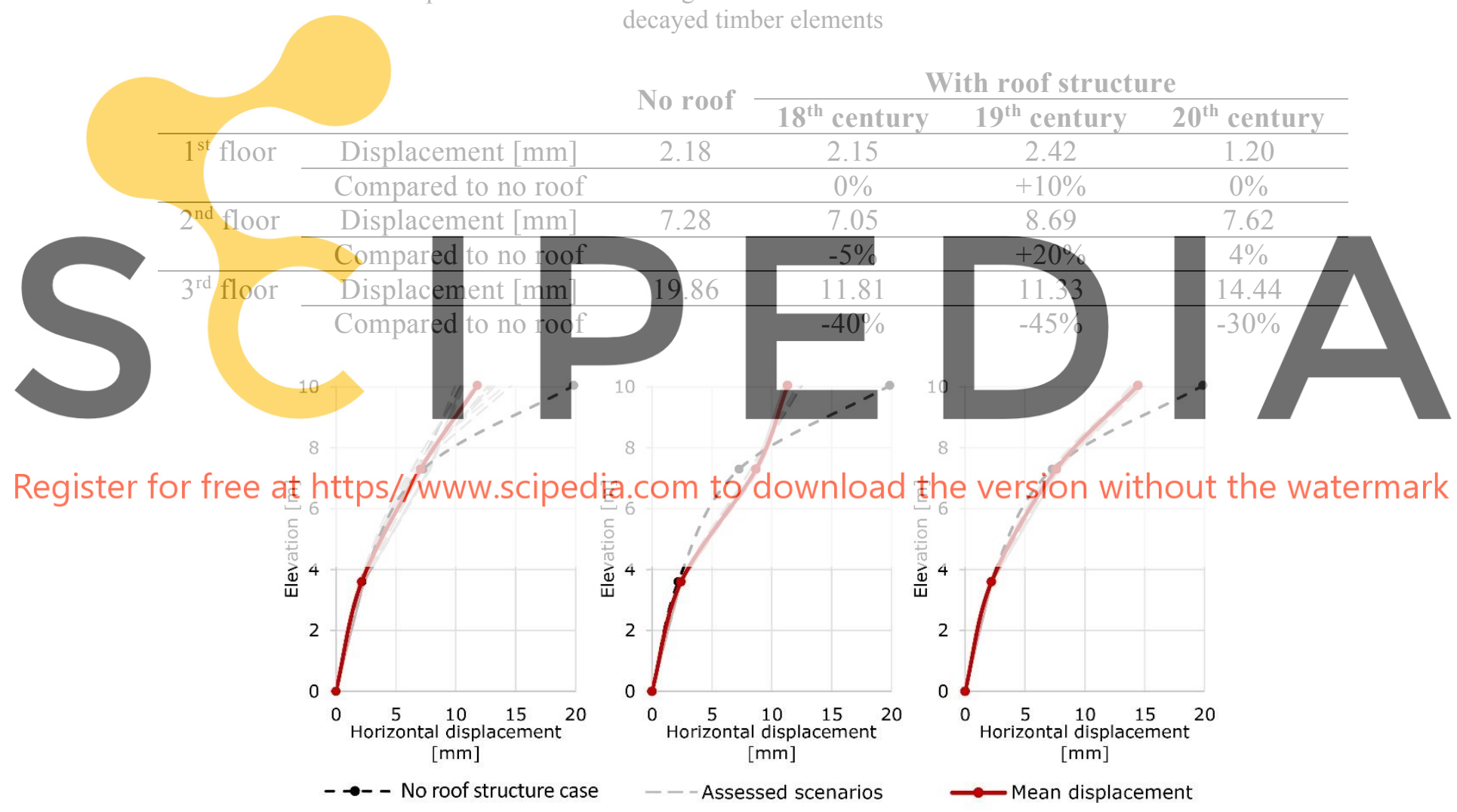

Figure 5: Horizontal out-of-plane displacement of the building without and with roof structure (a) $18^{\text {th }}$ century; b) $19^{\text {th }}$ century; c) $20^{\text {th }}$ century) with $20 \%$ decayed timber elements

\subsection{Out-of-plane inter-story drift}

The analysis of the out of plane inter-story drift is once again highlighting the different effect of each roof structure on the seismic behaviour of the building. The analysis clearly shows that the $18^{\text {th }}$ and $19^{\text {th }}$ century roof structures are presenting a clear decrease of the inter-story drift on the third floor of the building, the $19^{\text {th }}$ century roof structure presenting a clear decrease 
between the $2 \mathrm{nd}$ and $3 \mathrm{rd}$ floor of $35 \%$. The $20^{\text {th }}$ century roof structure, on that other hand, is presenting a steady increase of the inter-story drift starting with the first floor with a significant increase at the last floor of 55\% (Table 3).

Table 3: Mean inter-story drift of the building without a roof and with the three roof structures without decay

\begin{tabular}{cccccc} 
& & \multirow{3}{*}{ No roof } & \multicolumn{3}{c}{ With roof structure } \\
\cline { 3 - 6 } & & & 18th century & 19th century & 20th century \\
\hline \multirow{2}{*}{$\begin{array}{c}\text { 1st } \\
\text { floor }\end{array}$} & Interstory drift [mm] & 2.18 & 2.08 & 2.29 & 1.95 \\
\cline { 2 - 6 } & Interstory drift ratio [\%] & 0.06 & 0.06 & 0.06 & 0.05 \\
\cline { 2 - 6 } & Compared to no roof & & $-4.72 \%$ & $4.60 \%$ & $-10.68 \%$ \\
\hline \multirow{2}{*}{$\mathbf{2 n d}$} & Interstory drift [mm] & 5.10 & 4.47 & 5.48 & 4.37 \\
\cline { 2 - 6 } & Interstory drift ratio [\%] & 0.14 & 0.12 & 0.15 & 0.12 \\
\cline { 2 - 6 } & Compared to no roof & & $-12.41 \%$ & $7.56 \%$ & $-14.34 \%$ \\
\hline 3rd & Interstory drift [mm] & 12.58 & 3.67 & 3.67 & 9.39 \\
\cline { 2 - 6 } floor & Interstory drift ratio [\%] & 0.46 & 0.10 & 0.10 & 0.26 \\
\cline { 2 - 6 } & Compared to no roof & & $-70.82 \%$ & $-70.80 \%$ & $-25.37 \%$
\end{tabular}

The decay of the timber elements is emphasizing these changes. The presence of the $19^{\text {th }}$ century roof structure is decreasing the top out-of-plane inter-story drift with $60 \%$ compared to the second floor, while the presence of the $20^{\text {th }}$ century structure is increasing it with only $20 \%$, compared to the previous $55 \%$. The effect of the $18^{\text {th }}$ century roof structure is not as visible at

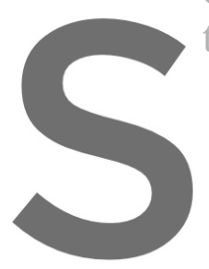
the top of the building (Table
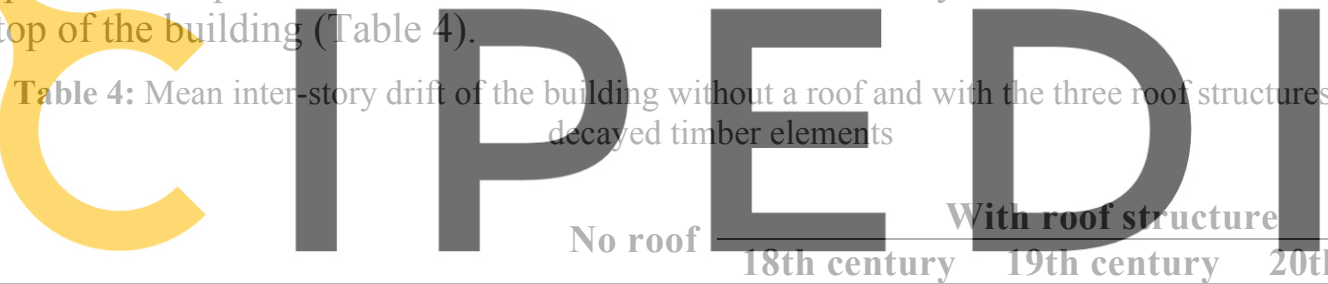

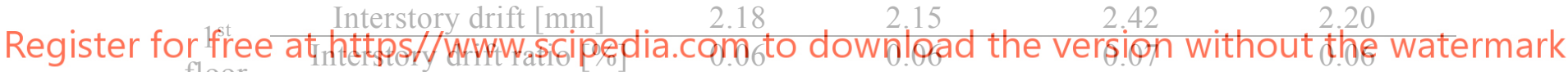

2.18 18th century

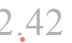
floor Compared to no roof

\begin{tabular}{ccc}
$2^{\text {nd }}$ & Interstory dinif [mm] & 5.1 \\
\cline { 2 - 3 } floor & Interstory drift ratio [\%] & 0.14 \\
\cline { 2 - 3 } & Compared to no roof \\
\hline \multirow{2}{*}{$3^{\text {rd }}$} & Interstory drift [mm] & 12.58 \\
\cline { 2 - 2 } floor & Interstory drift ratio [\%] & 0.46 \\
\cline { 2 - 3 } & Compared to no roof
\end{tabular}

5.10 4.90 $0.96 \%$

0.14 6.27

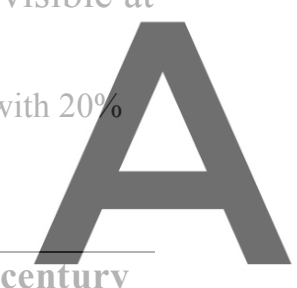

3.3 Deformed shape

As could be observed in the displacement and inter-story drift analysis, each roof structure is causing a different type of deformation of the historic masonry building. While the building without roof structure is clearly presenting a flexural deformation, the presence of the $18^{\text {th }}$ and $19^{\text {th }}$ century roof structure is causing a change to shear deformation for more than half of the considered scenarios, while the other scenarios are still presenting flexural deformation. If however, the timber elements are decayed, more scenarios are causing a flexural deformation of the building. The presence of the $20^{\text {th }}$ century roof structure, on the other hand, is presenting 
for both roof structure in a good state of conservation and $20 \%$ decayed timber elements, a clear flexural deformation.

\subsection{Damage level}

Further, in order to better understand the effect of the roof structure on the seismic behaviour of the building, the damage level, which would be recorded on the masonry walls was analysed (Table 5). Three different limit state were taken into consideration, according to the Eurocode, the Failure Mechanism Identification and Vulnerability Evaluation procedure (FaMIVE) and based on previously performed experimental campaigns [23].

Since the building without any roof structure is presenting significant damage both in-plane and out-of-plane but also considering the combined behaviour, the results show once again an improvement of the behaviour of the building due to the presence of the roof structures. It was observed that the presence of the $18^{\text {th }}$ century roof structure, in a good state of conservation, is presenting limited damage for almost all the limited states, both in-plane and out-of-plane. Still, if the roof structure is decayed, significant damages tend to also appear in-plane at the second and third floor of the building according to the FaMIVE limit state and at the third floor considering the combined prevalent behaviour.

The $19^{\text {th }}$ century roof structure is presenting a rather peculiar effect, since the presence of the roof structure in a good state of conservation is causing significant damage on the second and third floor of the building, considering the in-plane prevent behaviour but only on the third floor if the timber elem for the decayed roof struc floor. The $20^{\text {th }}$ century of the damage level, not for all the limit state of the roof structure is 1
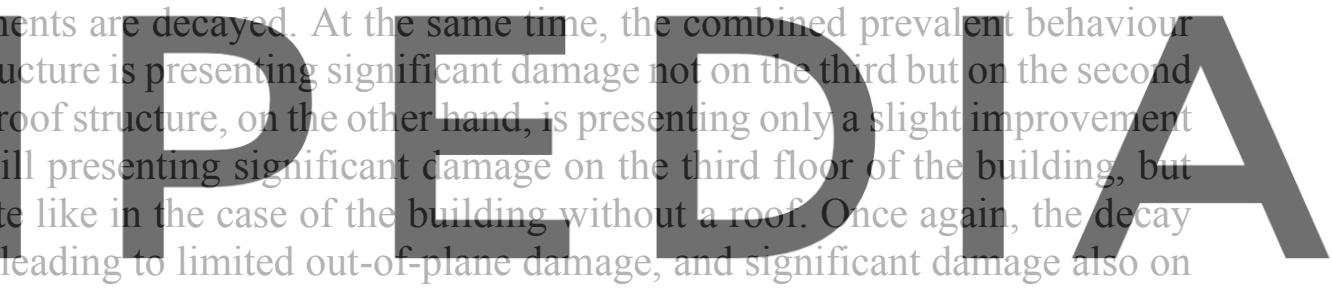

the second floor considering the in-plane prevalent behaviour.

Register for free at https//www scipedia.com to download the version without the watermark

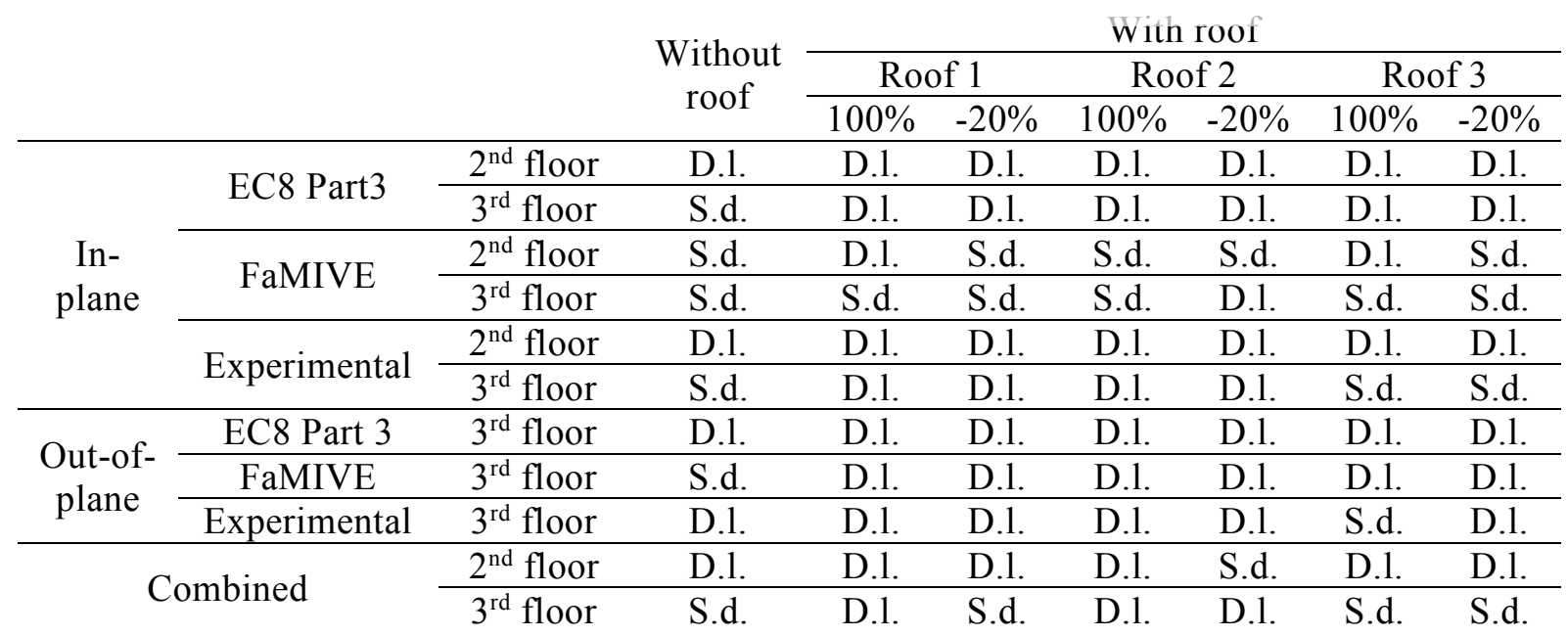




\subsection{Internal forces}

Ultimately, the internal forces were analysed, along the wall facing the street (Figure 3) by comparing the vertical axial forces $\left(\mathrm{N}_{\mathrm{x}}\right)$, the shear forces perpendicular to the walls $\left(\mathrm{V}_{\mathrm{z}}\right)$ and the out-of-plane bending moments $\left(\mathrm{M}_{\mathrm{y}}\right)$ and the differences between the building without roof structure and with the three roof.

For the roof structures in a good state of conservation (Figure 6), it was observed that the vertical axial forces are presenting only little changes on the first and second floor of the building. The main differences are highly visible on top of the third floor, where the first and third roof structure are presenting tensile axial forces and the presence of the second roof structure is causing higher compressive forces than in the case of the building without a roof.

The shear forces perpendicular to the wall present the same trend, with clear changes rather visible on the third floor where the $18^{\text {th }}$ century roof structure is presenting a $45 \%$ increase of the shear forces, the $19^{\text {th }}$ century a 4 times increase and the $20^{\text {th }}$ century an $40 \%$ increase. Remarkable is the influence of the cross-vault on the recorded shear forces since in all the three cases the forces are in the opposite direction compared to all the other floors.

The out-of-plane bending moment differences between the assessed cases, start to be visible above the top part of the second floor. It can be observed that the bending moments are high at the top part of the second floor, decrease at the base of the third and rise once again towards the top of the building. At the same time, it can also be observed that the presence of the $20^{\text {th }}$ century roof structure is causing the highest bending moment at the top of the second floor and the

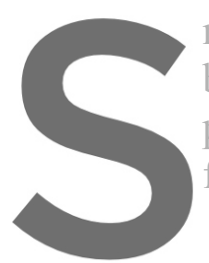
minimum at the top of bending moment at the presenting lower bending floor, and slightly higher

10.05

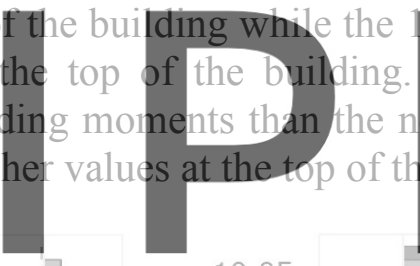

10.05

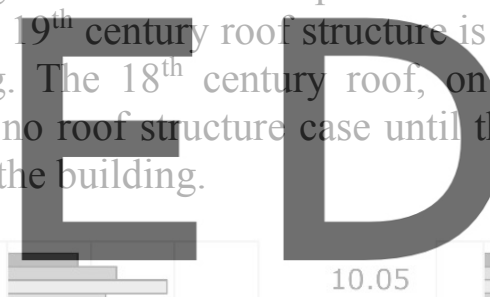

10.05
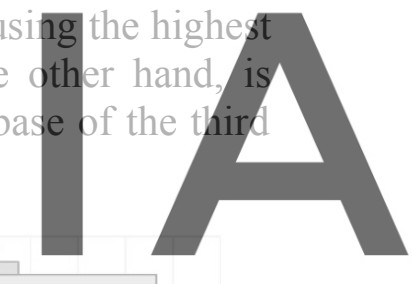

Register for free at https//WW.scipedia.eom to download the version without the watermark

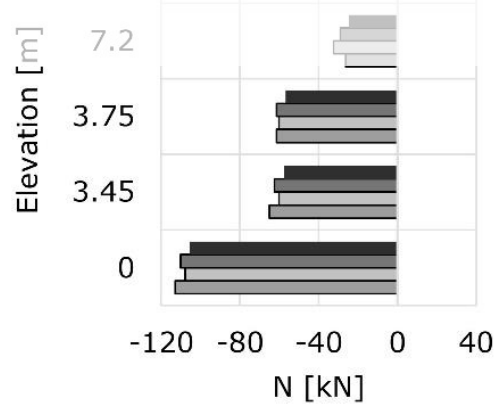

No roof

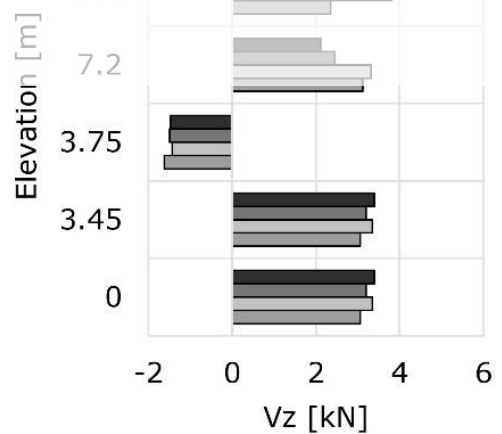

$\square$ Roof structure 2

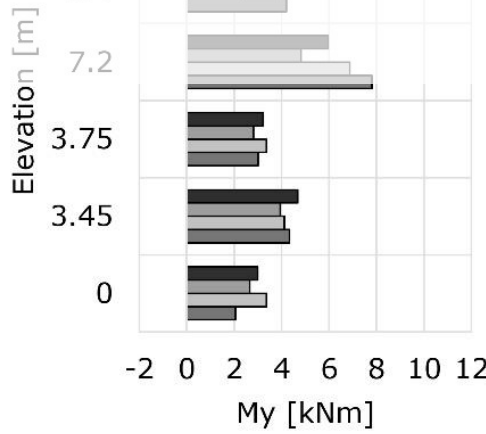

$\square$ Roof structure 3

Figure 6: Internal force diagrams of the building without and with roof structures (a) 18th century; b) 19th century; c) 20th century)

The decay of the roof structures is also changing the recorded internal forces (Figure 7). The axial forces are like in the case of the roof structures in a good state of conservation, approximately similar until the top of the second floor. Above this, the effect of the three roof 
structures is clearly visible. Therefore, it could be observed that the $18^{\text {th }}$ and $19^{\text {th }}$ century roof structures are causing tensile forces only at the top of the building, while the presence of the $20^{\text {th }}$ century roof structure is causing tensile forces also at the base of the third floor.

The shear forces perpendicular to the wall also present similar values until the base of the second floor, for all the four considered cases, but above this level, the effect of the roof structures is visible. Therefore, it could be observed that all the roof structures are causing an increase of the shear forces, of up to $30 \%$ for the $18^{\text {th }}$ century roof structure, up to $40 \%$ for the $20^{\text {th }}$ century roof and almost 2.5 times higher in the case of the $19^{\text {th }}$ century roof structure. As in the not decayed roof structure case, the presence of the cross-vault is still causing shear forces in the opposite direction.

The bending moments are also similar until the base of the second floor. Above this level, each roof structure is influencing the bending moments differently. The $18^{\text {th }}$ century and $19^{\text {th }}$ century roof structures are presenting lower values than the no roof structure case at the top of the second floor and base of the third. At the top of the building, the bending moments caused by the $18^{\text {th }}$ century roof is only slightly higher than the no roof structure ones, while the $19^{\text {th }}$ century ones are the highest when comparing all the four cases. The $20^{\text {th }}$ century roof structure, on the other hand, is presenting maximum bending moments at the top of the second floor and only slightly higher bending moments than the ones recorded for the no roof structure case on the top of the building.
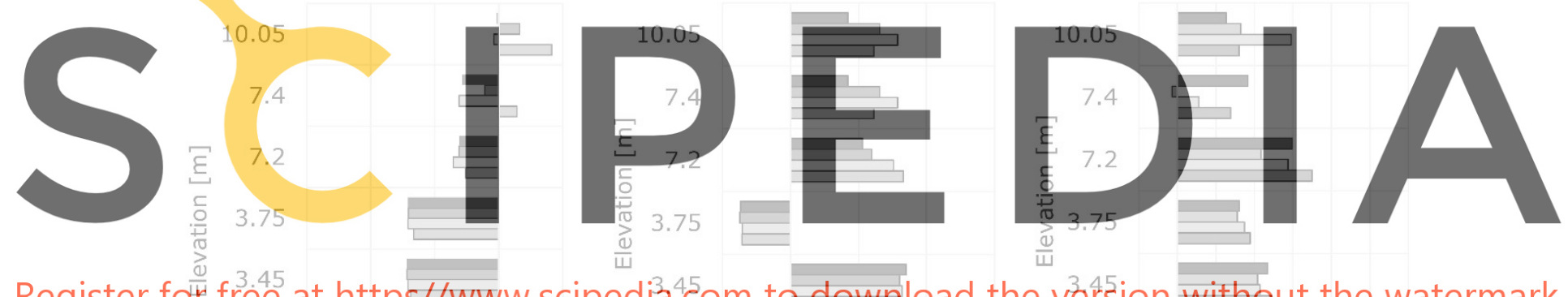

Register for free at https//WWW.scipedia.45om
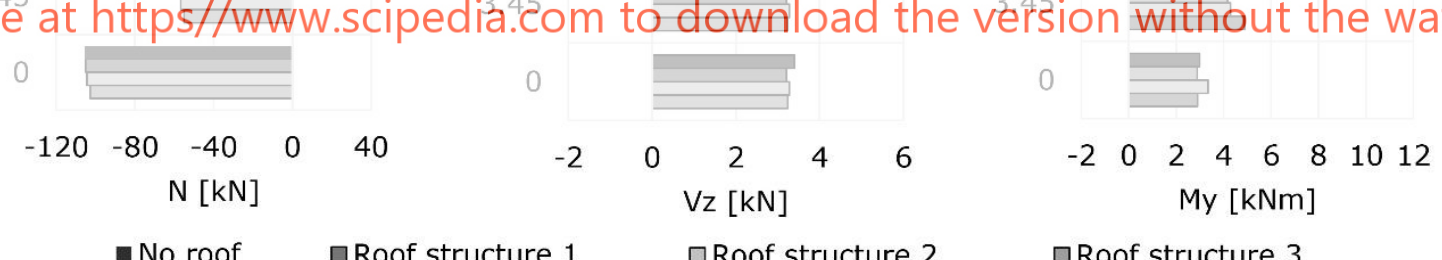

Figure 7: Internal force diagrams of the building without and with roof structures (a) 18th century; b) 19th century; c) 20th century) with $20 \%$ decayed timber elements

In both cases, for the roof structures in a good state of conservation or decayed, the obtained axial forces presented significant variations influenced by the chosen support type and joint stiffness.

\section{CONCLUSIONS}

The presented study is trying to bring forward that heritage buildings have to be regarded as a whole when addressing their seismic vulnerability and that roof structures are playing an important role. 
The numerical simulations performed on the $18^{\text {th }}$ century masonry building has brought forward that depending on the roof structure type, its state of conservation and the considered properties of the supports and joints:

1. The out-of-plane displacement can be reduced with 10 up to $55 \%$;

2. The inter-story drift can be reduced with up to $85 \%$;

3. The deformation of the historic masonry building can be changed from flexural to shear;

4. The damage level of the building after the seismic event can be improved;

5. Tensile vertical forces can appear at the top of the building;

6. Shear forces perpendicular to the wall and out-of-plane bending moments can suffer an increase at the top of the building.

7. Out-of-plane bending moments present a clear increase at the top of the building but lower values at the base of the last floor.

At the same time, the effect of the cross-vaults on the shear forces perpendicular to the wall was also observed, changing the direction of the forces.

Since roof structure types are diverse and highly influenced by local structural features, further studies, both laboratory and numerical are needed to be able to properly determine how various roof structure types are influencing the seismic behaviour of heritage buildings. In the same time, it is important to how interlinked these two parts of buildings are and introduce these new data in seismic vulnerability assessment methodologies developed for heritage buildings.

\section{REFERENCES}

[1] Parisi, M.A. and Chesi, C. Seismic vulnerability of traditional buildings: the effect of roof-masonry walls interaction. In: Tenth U.S. National Conference on Earthquake Engineering Frontiers of Earthquake Engineering. Anchorage, Alaska (2014).

[2] Keller, A. Chieffo, N. and Mosoarca, M. Influence of roof structures on seismic behavior of historic buildings. In: Mazzolani F (eds.). 3rd International Conference on Protection Of Historical Constructions, PROHITECH'17 (2017).

[3] Touliatos, P. Traditional aseismic techniques in Greece. In: Mendés V (eds.). Proceedings of the Interantional Workshop Les sytèmes nationaux faces aux seismes majeurs. Lisbon, Portugal, (1993), pp. 110-124.

[4] Ortega, J. Vasconcelos, G. Rodrigues, H. and Correia, M. Local seismic cultures: The use of timber frame structures in the south of Portugal. In: Cruz H (eds.). Historical Earthquake-Resistant Timber Framing in the Mediterranean Area. Springer, (2016), pp. 101-111.

[5] Parisi, M.A. and Piazza, M. Seismic behavior and retrofitting of joints in traditional timber roof structures. Soil Dyn Earthq Eng (2002) 22(9-12):1183-1191.

[6] Parisi, M.A. Chesi, C. Tardini, C. and Piazza, M. Seismic vulnerability and preservation of timber roof structures. In: Dina D (eds.). Structural Analysis of Historic Construction.Bath, United Kingdom, (2008), pp. 1253-1260.

[7] Touliatos, P. The box framed entity and function of the structures: the importance of wood's role. In: Conservation of historic wooden structures: proceedings of the international conference. Florence, Italy, (2005), pp. 52-64.

[8] Giongo, I. Dizhur, D. Tomasi, R. and Ingham, J.M. In-plane assessment of existing timber diaphragms in URM buildings via quasi-static and dynamic in-situ tests. In: 
Advanced Materials Research. (2013), pp. 495-502.

[9] Parisi, M.A. Chesi, C. and Tardini, C. The role of timber roof structures in the seismic response of traditional buildings. In: 15th World Conference on Earthquake Engineering.Lisbon, Portugal, (2012).

[10] Parisi, M.A. Chesi, C. Tardini, C. and Piazza, M. Seismic vulnerability assessment for timber roof structures. In: The 14th World Conference on Earthquake Engineering.Beijing, China, (2008), pp. 12-17.

[11] Keller, A. Parisi, M.A. Tsakanika, E. and Mosoarca, M. Influence of historic roof structures on the seismic behaviour of masonry structures. Proc Inst Civ Eng - Struct Build (2019):1-27.

[12] Nemetschek. SCIA Engineer User Manual. (2013).

[13] Marin, M. Roman, L. and Roman, O. Earthquakes in the Banat area - Timisoara (in Romanian). Bul AGIR (2011) 2:23-27.

[14] Oros, E. Earthquakes in the Banat plain (in Romanian). Graffiti, Timisoara, Romania, (1991).

[15] Oros, E. and Diaconescu, M. Recent vs. historical seismicity analysis for Banat seismic region (western part of Romania). In: Vacareanu R (eds.). Proceedings of the 5th National Conference on Earthquake Engineering and 1st National Conference on Earthquake Engineering and Seismology. CONSPRESS, (2014)

[16] Oros, E. Popa, M. and Moldovan, I.A. Seismological database for Banat seismic region (Romania)-part 1: the parametric earthquake catalogue. Rom J Phys (2008) 53(7-8):955964.

[17] Descamps, T. and Lemlyn, P. Effects of the rotational, axial and transversal stiffness of the joints on the static response of old timber framings. In: Mazzolani F (eds.). Protection of Historical Buildings, PROHITECH 09. CRC Press, Taylor \& Francis Group, Rome, Itlay, (2009), pp. 291-286.

[18] Branco, J.M. and Descamps, T. Analysis and strengthening of carpentry joints. Constr Build Mater (2015) 97:34-47.

[19] Heimeshoff, B. and Kohler, N. Assessment of the structural behaviour of timber joints (in german). Munchen, (1989).

[20] Meisel, A. Historische Dachwerke Beurteilung, realitätsnahe statische Analyse und Instandsetzung. Monographi. Verlag der Technischen Universität Graz, Graz, (2015).

[21] Holzer, S.M. Statische Beurteilung historischer Tragwerke. Band 2, Holzkonstruktionen. Wiley-VCH Verlag GmbH \& Co. KGaA, Weinheim, Germany, (2015).

[22] Holzer, S.M. Analysis of historical timber structures. In: Van Balen \& Verstrynge (eds.). Structural Analysis of Historical Constructions - Anamnesis, diagnosis, therapy, controls.Taylor \& Francis Group, Leuven, Belgium, (2016), pp. 1203-1210.

[23] Vicente, R. D’Ayala, D. Ferreira, T.M. Varum, H. Costa, A. da Silva, M. et al. Seismic vulnerability and risk assessment of historic masonry buildings. In: Structural Rehabilitation of Old Buildings. (2014), pp. 307-348. 